\title{
THE EFFECT OF ACTIVE, CREATIVE, EFFECTIVE, AND FUN (PAKEM) LEARNING MODEL ON STUDENTS' LEARNING OUTCOMES AT GRADE V SD
}

\author{
Ernarita Ndruru$^{1}$, Saut Mahulae ${ }^{2}$, Dewi Anzelina ${ }^{3}$, Patri Janson Silaban ${ }^{4}$ \\ 1,2,3,4 Universitas Katolik Santo Thomas, Medan, Indonesia \\ 1ernaritandruru@gmail.com, 2mahulaesaut@gmail.com, ${ }^{3}$ dewianzelina1988@gmail.com, \\ ${ }^{4}$ patri.jason.silaban@gmail.com
}

\begin{abstract}
This study aimed to determine the effect of PAKEM learning model on students' learning outcomes on the Ecosystem theme at grade $V$ SD Negeri 067246 Medan in the academic year 2020/2021. The population of this study were all students of grade V SDN 067246 Medan Tuntungan totaling 30 students.The method used in this research was descriptive method. The results of this study indicated that students' learning outcome by using the PAKEM model was in very good category with an average of 81.03. Besides, the normality test obtained that the significance value of learning outcomes

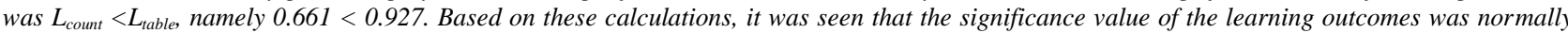
distributed. In the correlation test, the coefficient value was 0.652 meaning that $r_{\text {count }}>r_{\text {table }}$ that was 0.361 . Thus, there was a strong influence between PAKEM model on students' learning outcomes with the theme of Ecosystem at grade V SDN 067246 Medan. The results of the $t$-test found that $t_{\text {count }}>$ $t_{\text {table }}$ or $4.550>1.701$ so that Ha was accepted. This showed that there was a significant positive effect of the influence of PAKEM learning model on students' learning outcomes on the Ecosystem theme for grade V SDN 067246 Medan Tuntungan for the academic year $2020 / 2021$.
\end{abstract}

Keywords: learning outcomes, ecosystem, pakem learning model

\section{PENGARUH MODEL PEMBELAJARAN AKTIF KREATIF EFEKTIF DAN MENYENANGKAN (PAKEM) TERHADAP HASIL BELAJAR SISWA KELAS V SD}

\begin{abstract}
ABSTRAK
Penelitian ini bertujuan untuk mengetahui pengaruh model pembelajaran PAKEM terhadap hasil belajar siswa pada Tema Ekosistem di kelas V SD Negeri 067246 Medan Tahun Pembelajaran 2020/2021. Populasi penelitian ini adalah seluruh siswa kelas V SDN 067246 Medan Tuntungan berjumlah 30 siswa. Metode yang digunakan dalam penelitian ini adalah metode deskriptif. Hasil penelitian ini menunjukkan bahwa hasil belajar siswa menggunakan model PAKEM termasuk kategori baik sekali dengan rata-rata 81.03. Pengujian normalitas diperoleh nilai signifikansi hasil belajar adalah Lhitung <Ltabel yaitu $0.661<0.927$. Berdasarkan perhitungan tersebut dapat diketahui bahwa nilai signifikansi dari hasil belajar berdistribusi normal. Pada pengujian korelasi, nilai koefisien sebesar 0.652 artinya rhitung > rtabel yaitu 0.361 . Maka terdapat pengaruh yang kuat antara model PAKEM terhadap hasil belajar siswa dengan tema Ekosistem kelas V SDN 067246 Medan. Hasil pengujian uji-t thitung > ttabel yaitu 4.550>1.701 sehingga $\mathrm{H}_{\mathrm{a}}$ diterima. Hal ini menunjukkan adanya pengaruh positif signifikansi dari pengaruh Model pembelajaran PAKEM terhadap hasil belajar siswa pada tema Ekosistem kelas V SDN 067246 Medan Tuntungan Tahun Pembelajaran 2020/2021.
\end{abstract}

Kata Kunci: hasil belajar, ekosistem, model pembelajran pakem

\begin{tabular}{|c|c|c|}
\hline Submitted & Accepted & Published \\
\hline 01 Juli 2021 & 09 Agustus 2021 & 16 September 2021 \\
\hline
\end{tabular}

\begin{tabular}{|l|c|c|}
\hline Citation & $:$ & $\begin{array}{r}\text { Ndruru, E., Mahulae, S., Anzelina, D., Silaban, P.J. (2021). The Effect of Active, Creative, Effective, and Fun (PAKEM) } \\
\text { Learning Model on Students' Learning Outcomes at Grade V SD. Jurnal PAJAR (Pendidikan dan Pengajaran), } \\
5(5), 1296-1305 . \text { DOI : http://dx.doi.org/10.33578/pir.v5i5.8457. }\end{array}$ \\
\hline
\end{tabular}

\section{PENDAHULUAN}

Pendidikan merupakan sesuatu yang sangat fundamental bagi setiap individu. Oleh karena itu, kegiatan pendidikan tidak dapat diabaikan begitu saja, terutama dalam memasuki era persaingan yang semakin ketat, tajam, berat pada abad milenium ini.
(Hamdani 2018) Pendidikan dilaksanakan secara terencana dan sistematis agar tujuan pendidikan dapat tercapai sesuai dengan harapan melalui kegiatan pembelajaran yang efektif dan efesien. Kegiatan pembelajaran terdiri atas perencanaan, pelaksanaan dan penilaian. 
perencanaan mencakup pembuatan silabus dan Rencana Pelaksanaan Pembelajaran (RPP). Melalui perencanaan diharapkan kegiatan pembelajaran menjadi terarah sesuai dengan tujuan yang ditentukan. Pelaksanaan pembelajaran meliputi kegiatan penyampaian materi dengan menggunakan strategi atau metode serta media tertentu supaya pembelajaran berjalan efektif.

Menurut Anzelina (2019: 752) bahwa, "Pendidikan merupakan hal pokok yang dapat mendukung serta menunjang kemajuan suatu bangsa". Melalui pendidikan, diharapkan kualitas dari suatu individu atau bahkan suatu kelompok/komunitas dapat meningkat dengan baik. pendidikan memegang peranan yang sangat penting untuk mencetak manusia yang professional serta dapat bekerja secara individu maupun kelompok. Maka dari itu, pendidikan dituntut untuk memiliki mutu yang dapat melahirkan generasi yang baru yang baik bagi bangsa.

Model pembelajaran PAKEM dalam kelas sangat mempengaruhi tercapainya hasil belajar siswa. salah satunya adalah pengaruh model pembelajaran PAKEM terhadap hasil belajar siswa dimana model pembelajaran PAKEM pada dasarnya merupakan suatu proses dimana guru dapat mempengaruhi siswa yang didalamnya berisi serangkaian tindakan atau perilaku tertentu terhadap masing-masing siswa yang dipengaruhinya. Dengan model pembelajaran yang tepat yang digunakan dalam sistem belajar dikelas akan mengobtimalkan dan memaksimalkan keberhasilan pembelajaran dikelas serta membangkitkan minat belajar siswa untuk mendapatkan hasil belajar yang baik.

Berdasarkan hasil observasi di kelas $\mathrm{V}$ SDN 067246 Medan Tuntungan dengan Ibu Elizabets Sitinjak, Amd, ditemukan beberapa hal faktor dari luar yang mempengaruhi hasil belajar siswa. Faktor-faktor tersebut antara lain, sikap guru yang tidak menentu, pengelolaan kelas, penggunaan media pembelajaran, pihak orang tua siswa. Sikap guru yang tidak menentu selama proses pembelajaran mempengaruhi hasil belajar siswa. Kadang masih ada sikap guru otoriter, sikap guru yang tertutup pada siswa begitu juga siswa tertutup pada guru. Terkadang masih ada juga guru yang kurang memperhatikan siswanya, sehingga siswa kurang perduli selama proses pembelajaran.

Tabel 1. Nilai Ulangan Harian Pembelajaran Tematik di Kelas V

\begin{tabular}{cccccc}
\hline No & $\begin{array}{c}\text { Mata } \\
\text { Pelajaran }\end{array}$ & $\begin{array}{c}\text { Jumlah } \\
\text { Siswa }\end{array}$ & KKM & Presentase\% & Keterangan \\
\hline \multirow{2}{*}{1} & Bahasa & 30 & 70 & $66.7 \%$ & Tidak Tuntas \\
& Indonesia & & & $33.3 \%$ & Tuntas \\
2 & IPA & 30 & 70 & $73.3 \%$ & Tidak Tuntas \\
& & & & $26.7 \%$ & Tuntas \\
\hline
\end{tabular}

Berdasarkan hasil nilai ulangan diketahui bahwa Kriteria Ketuntasan Minimum (KKM) yang sudah ditentukan yaitu 70. Di mata pelajaran Bahasa Indonesian terdapat 20 siswa dari 30 siswa atau $66.7 \%$ siswa yang tidak mencapai KKM, sedangkan siswa yang mencapai KKM berdasarkan tabel diatas terdapat 10 siswa dari 30 siswa atau $33.3 \%$ siswa yang mencapai KKM. Sedangkan di mata pelajaran IPA terdapat 22 siswa dari 30 siswa atau $73.3 \%$ siswa yang tidak mencapai KKM, sedangkan siswa yang mencapai
KKM berdasarkan tabel diatas terdapat 8 siswa dari 30 siswa atau $26.7 \%$ siswa yang mencapai KKM. Hal tersebut menunjukkan terdapat suatu masalah yang menyebabkan rendahnya hasil belajar siswa.

PAKEM salah satu pendekatan yang berorientasi untuk menggali dan mengembangkan pontesi terbesar siswa dengan metodologi pembelajaran yang mengedepankan keaktifan anak, mendorong kreatifitas, efektif dalam pencapaian target dan kualitas, serta 
menyenangkan dalam proses pembelajaran. Menurut Budimansyah, Suparlan, \& Meirawan., (2008: 70) bahwa, "PAKEM adalah singkatan dari pembelajaran Aktif, Kreatif, Efektif, dan Menyenangkan".

a. Aktif

Aktif dimaksudkan bahwa dalam proses pembelajaran guru harus meciptakan suasana sedemikian rupa sehingga peserta didik aktif mengajukkan pertanyaan, mengemukakan gagasan, dan mencari data dan informasi yang mereka perlukan untuk memecahkan masalah.

b. Kreatif

Kreatif dimaksudkan agar guru menciptakan kegiatan belajar yang beragam sehingga memenuhi beberapa tingkat kemampuan siswa.

c. Efektif

Efektif yaitu tidak menghasilkan apa yang harus dikuasai siswa setelah proses pembelajaran berlangsung, sebab pembelajaran memiliki sejumlah tujuan pembelajaran yang harus dicapai.

d. Menyenangkan

Menyenangkan adalah suasana belajarmengajar yang menyenangkan sehingga siswa memusatkan perhatiannya secara penuh pada belajar sehingga waktu curah perhatiannya tinggi.

Menurut Sidabuta (2019:20) bahwa, "PAKEM adalah singkatan dari pembelajaran Aktif, Kreatif, Efektif dan Menyenangkan. Atau bisa dikatakan sebuah model pembelajaran Aktif, Kreatif, Efektif dan Menyenangkan, yang hal tersebut ditunjukkan sebagai alternative serta solusi dalam meningkatkan kualitas pembelajaran di sekolah khususnya di sekolah dasar". Model pembelajaran Pakem dalam kelas sangat mempengaruhi tercapainya hasil belajar siswa. Salah satunya adalah pengaruh model pembelajaran PAKEM terhadap hasil belajar siswa dimana model pembelajaran PAKEM pada dasarnya merupakan suatu proses dimana gura dapat mempengaruhi siswa yang didalamnya berisi serangkaian tindakan atau perilaku tertentu terhadap masing-masing siswa yang dipengaruhiny.

Menurut Sidabutar Jessica (2019: 19)

bahwa, "Bahwa PAKEM merupakan model pembelajaran dan menjadi pendoman dalam bertindak untuk mencapai tujuan yang telah ditetapkan". Ia membagi model-model pembelajaran menjadi: model pembelajaran kontekstual, koperatif, berbasis masalah, tematik, berbasis computer, PAKEM, berbasis Web, pembelajaran mandiri. PAKEM merupakan sebuah pendekatan yang memungkinkan peserta didik mengerjakan kegiatan beragam untuk mengembangkan keterampilan, sikap dan pemahamannya dengan penekanan belajar sambil bekerja. Sementara, guru menggunakan berbagai sumber dan alat bantu belajar, termasuk pemanfaatan lingkungan supaya pembelajaran lebih menarik, menyenangkan dan efektif.

Kata atau istilah belajar bukanlah sesuatu yang baru sudah sangat dikenal secara luas, Belajar merupakan suatu proses yang kompleks yang terjadi pada diri setiap orang sepanjang hidupnya, proses belajar itu terjadi karena adanya interaksi antara dengan seseorang dengan lingkungannya. belajar dapat terjadi dimana saja dan kapan saja. Salah satu pertanda bahwa seseorang itu telah belajar adalah dengan adanya perubahan tingkah pengetahuan, keterampilan dan sikapnya.

Pada proses belajar mengajar guru memegang peranan penting dalam pembelajaran di kelas, dan guru tersebut tidak bisa mengajar tanpa adanya siswa. Siswa bisa belajar tanpa adanya guru, keberhasilan dalam proses pembelajaran dapat dilihat dari ketercapaian tujuan pembelajaran yang ditentukan. Belajar suatu perubahan perilaku, akibat interaksi dengan lingkungan. Perubahan perilaku dalam proses belajar terjadi akibat dari interaksi dengan lingkungan. Interaksi biasanya berlangsung secara sengaja. Dengan demikian belajar dikatakan berhasil apabila terjadi perubahan dalam diri individu.

Kemudian menurut Aslinda, (2017: 474) bahwa, "belajar diartikan sebagai suatu perubahan tingkah laku dalam diri seseorang yang relative menetap dari sebuah hasil pengalaman". Maksudnya disini adalah dengan kita belajar seseorang dapat mengalami perubahan sesuai apa yang pernah dialaminya selama hidupnya, dan belajar juga dapat meningkatkan pertumbuhan dan perkembangan seseorang kearah yang lebih baik lagi. Menurut Mahulae \& Silaban , (2020: 309) bahwa"Belajar adalah aktivitas terencana yang 
terjadi pada semua orang dan berlangsung sepanjang hidup". Yang didapatkan berkat pengalaman dan latihan, agar tingkah laku seseorang mengalami perubahan yang lebih baik. belajar yang efektif dapat membantu siswa untuk meningkatkan kemampuan yang diharapkan sesuai dengan tujuan intruksional yang ingin dicapai.

Berdasarkan paparan di atas menurut para ahli, dapat disimpulkan bahwa pengertian belajar adalah suatu aktivitas atau pengalaman yang memotivasi seseorang menghasilkan perubahan pengetahuan dan tingkah laku karena adanya pengalaman yang dilakukan dalam kegiatan belajar. karena belajar adalah usaha seseorang untuk memperoleh pengetahuan, kecakapan serta pengalaman baru yang memungkinkan terjadinya perubahan tingkah laku terhadap interaksi dengan lingkungannya.

Dalam proses pembelajaran perubahan seseorang sangat penting. Guru memberikan nilai kepada siswa tentu karena siswa belajar. Hasil pembelajaran merupakan suatu pernyataan yang spesifik yang dinyatakan dalam perilaku dan penampilan yang diwujudkan dalam bentuk tulisan untuk menggambarkan hasil belajar yang diharapkan. Perilaku ini dapat berupa fakta yang konkrit serta dapat dilihat dan fakta yang tersamar. Oleh karena itu, hasil pembelajaran adalah suatu pernyataan yang jelas dan menunjukkan penampilan atau keterampilan siswa tertentu yang diharapkan dapat dicapai sebagai hasil belajar.

Hasil belajar siswa dipengaruhi oleh kemampuan siswa dan kualitas pengajaran. Kualitas pengajaran yang dimaksud adalah profesional yang dimiki oleh guru. Artinya kemampuan dasar guru baik di bidang kognitif (intelektual), bidang sikap (afektif) dan bidang perilaku (psikomotorik). Menurut Istirani \& Pulungan, (2019: 19) bahwa, "Kegiatan pembelajar yang dibangun oleh guru dan siswa adalah kegiatan yang berhasil". Sebagai kegiatan yang berhasil, maka segala sesuatu yang dilakukan guru dan siswa hendaknya diarahkan untuk mencapai hasil yang telah ditentukan. Dengan demikian dalam setting pembelajar, hasil merupakan peningkat segala aktivitas guru dan siswa.
Menurut Istirani \& Pulungan, (2019: 19) bahwa, "bahwa hasil pengajaran merupakan komponen utama yang terlebih dahulu harus dirumuskan guru dalam proses belajar mengajar". Perana hasil ini sangat penting, karena merupakan sasaran dari proses belajar mengajar, penuangan hasil pembelajar dalam RPP bukan saja memperjelas arah yang ingin dicapai dalam suatu kegiatan belajar, tetapi dari segi efisiensi diperoleh hasil yang maksimal.

Menurut Istirani \& Pulungan, (2019b: 20) bahwa, pada tingkat yang amat umum sekali, hasil pembelajaran dapat diklasifikasikan menjadi 3 (tiga), yaitu:

\section{Keefektifan (effectiveness)}

pembelajaran biasanya diukur dengan tingkat pencapaian si belajar. Ada 4 (empat) aspek penting yang dapat dipakai untuk mempreskripsikan keefektifan pembelajaran, yaitu (1) kecermatan penguasaan perilaku yang dipelajari atau sering disebut dengan 'tingkat kesalahan', (2) kecepatan untuk kerja, (3) tingkat alih belajar, dan (4) tingkat retensi dari apa yang dipelajari.

\section{Efisiensi (efficiency)}

Efisiensi pembelajaran biasanya diukur dengan rasio antara keefektifan dan jumlah waktu yang dipakai di belajar dan atau jumlah biaya pembelajaran yang digunakan.

3. Daya Tarik (appeal)

Daya tarik pembelajaran biasanya diukur dengan mengamati kecenderungan siswa untuk tetap belajar. Daya tarik pembelajaran erat sekali kaitannya dengan daya tarik bidang studi, di mana kualitas pembelajaran biasanya akan mempengaruhi keduanya. Itulah sebabnya, pengukuran kecenderungan siswa untuk terus atau tidak harus belajar dapat dikaitkan dengan proses pembelajaran itu sendiri atau dengan bidang studi.

Hasil pengajaran merupakan komponen utama yang terlebih dahulu harus dirumuskan guru dalam proses belajar mengajar". Perana hasil ini sangat penting, karena merupakan sasaran dari proses belajar mengajar, penuangan hasil pembelajar dalam RPP bukan saja memperjelas arah yang ingin dicapai dalam suatu kegiatan belajar, tetapi dari segi efisiensi diperoleh hasil yang maksimal. 
Berdasarkan pemaparan di atas, maka peneliti menyimpulkan bahwa hasil pembelajar adalah suatu pernyataan yang spesifik yang dilakukan oleh guru untuk membentuk guru dalam sistem pembelajar atau proses belajar mengajar. Hasil belajar juga merupakan keberhasilan yang dicapai oleh siswa baik yang menyangkut aspek kognitif, afektif, dan psikomotorik yang diwujudkan dalam bentuk angka yang diperoleh melalui test yang diberikan kepada setiap siswa setelah melalui proses pembelajaran.

\section{METODE PENELITIAN}

\section{Pendekatan dan Metode Penelitian}

Metode penelitian adalah teknik atau cara yang digunakan peneliti sehubungan dengan penelitian yang akan dilakukan secara sistematis. Menurut Anzelina, Sinaga, \& Silaban,. (2021: 106) bahwa, "Metode penelitian merupakan cara ilmiah untuk mendapatkan data dengan tujuan dan kegunaan tertentu yang didasarkan pada ciri-ciri keilmuan yaitu, rasional, empiris, dan sistematis". Penelitian salah satu hal yang penting dalam pengembangan ilmu pengetahuan dan pendidikan, sekaligus sebagai bagian yang penting dalam perkembangan peradaban manusia.

Metode yang digunakan dalam penelitian ini adalah metode deskriptif. Berdasarkan masalah yang diteliti, peneliti menggunakan bentuk metode deskriptif merupakan metode penelitian yang bermaksud menjelaskan kedudukan variabel yang diteliti serta pengaruh antara suatu variabel dengan variabel yang lain.

Pendekatan yang digunakan dalam penelitian ini adalah pendekatan kuantitatif. Menurut Anzelina, Sinaga, \& Silaban,. (2021: 105) bahwa "Pendekatan kuantitatif merupakan metode untuk menguji teori-teori tertentu dengan cara meneliti hubungan antar variabel". Alasan peneliti menggunakan jenis penelitian ini karena peneliti ingin mengetahui adakah perbedaan yang signifikan terhadap hasil belajar siswa dalam menggunakan metode penelitian dekriptif.

\section{Rancangan atau Desain Penelitian}

Penelitian diartikan sebagai suatu proses pengumpulan dan analisis data yang dilakukan secara sistematis dan logis untuk mencapai tujuan- tujuan tertentu. Menurut Noor (2017 : 108) bahwa" Desain penelitian adalah semua proses yang diperlukan dalam perencanaan dan pelaksanaan penelitian". Dalam penelitian ini desain penelitian korelasi bertujuan untuk mengetahui hubungan antara dua variabel atau lebih. Pada penelitian ini terdapat dua variabel yaitu variabel bebas dan variabel terikat. Rancangan atau desain merupakan struktur dan rencana yang disusun secara sedemikian rupa agar mendapat jawaban atas masalah-masalah dalam penelitian. Dalam penelitian ini terdapat dua variabel yaitu variabel bebas dan variabel terikat. Variabel bebas (independen) yang diberi notasi huruf $(\mathrm{X})$ dan variabel terikat merupakan variabel yang mempengaruhi variabel terikat. Variabel terikat (dependen) yang diberi notasi huruf (Y) merupakan variabel yang dipengaruhi variabel bebas.

\section{Populasi dan Sampel Penelitian Populasi}

Populasi dapat diartikan sebagai keseluruhan subjek penelitian. Menurut Sugiyono (2017 : 80) bahwa, "Populasi adalah wilayah generalisasi yang terdiri atas: Obyek/subyek yang mempunya kualitas dan karakteristik tertentu yang ditetapkan oleh peneliti untuk dipelajari dan kemudian ditarik kesimpulannya". Populasi dalam penelitian ini adalah seluruh kelas V SDN 067246 Medan Tuntungan dengan jumlah 30 orang siswa.

\section{Sampel Penelitian}

Menurut Sugiyono (2017 : 80) bahwa, “ Sampel adalah bagian dari jumlah dan karakteristik yang dimiliki oleh populasi tersebut". Sampel penelitian ini adalah Kelas V SDN 067246 Medan Tuntungan Tahun Pembelajaran 2020/2021 yang berjumlah 30 siswa. pengambilan sampel pada penelitian ini dilakukan Boring Sampling (Sampling Jenuh). Noor (2017 : 156) bahwa, "Boring Sampling adalah sampel yang mewakili jumlah populasi. Biasanya dilakukan jika populasi dianggap kecil atau kurang dari 100". 
Jenis dan Sumber Data

Data adalah hasil pencatatan peneliti, baik yang berupa fakta maupun angka. Menurut Sugiyono (2018: 225) bila dilihat dari sumber datanya, maka pengumpulan data dapat menggunakan jenis data primer dan jenis data sekunder. Data primer adalah sumber data yang langsung memberikan data kepada pengumpulan data,dan data sekunder merupakan sumber yang tidak langsung memberikan kepada pengumpulan data, dan data sekunder merupakan sumber yang tidak langsung memberikan kepada pengumpul data. Dalam penelitian ini jenis data yang digunakan oleh peneliti adalah jenis data primer yang langsung diperoleh dari subjek peneliti. Sumber data dalam penelitian ini adalah siswa kelas V SDN 067246 Medan Tuntungan Tahun Pembelajaran 2020/2021. Menurut Arikunto (2018 : 172) bahwa, "Sumber data dalam penelitian adalah subjek dari mana data dapat diperoleh". Dalam penelitian ini, sumber data yang digunakan adalah 30 orang siswa kelas V SDN 067246 Medan Tuntungan Tahun Pembelajaran 2020/2021.

\section{Tes (Instrumen)}

Untuk mengetahui dan mengukur tes yang valid dan reliabel, maka peneliti menyajikan tes pilihan berganda untuk 30 orang siswa.

\section{Angket}

Angket merupakan suatu teknik pengumpulan data dengan memberikan atau menyebarkan daftar pertanyaan kepada responden. Menurut Sugiyono (2017 : 142), "Kuesioner merupakan teknik pengumpulan data yang dilakukan dengan cara memberi seperangkat pernyataan atau pertanyaan tertulis kepada responden untuk dijawab oleh siswa". Pertanyaan atau pernyataan yang akan diberikan peneliti kepada siswa berjumlah 15 butir soal.

\section{Dokumentasi}

Selain menggunakan alat tes, peneliti ini menggunakan teknik studi dokumentasi.Studi dokumentasi ini adalah suatu teknik pengumpulan data dengan menghimpun dan menganalisis dokumen tertulis maupun tidak tertulis.Menurut
Jakni (2016: 93) studi dokumentasi adalah, "Cara mengumpulkan data melalui dokumen-dokumen yang diperlukan dalam melengkapi data yang berhubungan dengan penyelidikan, yaitu dokumen tertulis maupun tidak tertulis".

\section{Uji Prasyarat Data}

\section{Uji Normalitas}

Uji normalitas akan dilakukan untuk mengetahui apakah populasi berdistribusi normal apa tidak. Uji normalitas dilakukan dengan menggunakan uji Liliefors, Menurut Noor (2017 : 174-175) bahwa, langkah-langkah seperti berikut ini adalah:

a. Susun data sampel dari yang kecil sampai yang terbesar dan tentukan frekuensi tiap-tiap data.

b. Tentukan nilai z dari tiap-tiap data tersebut.

c. Tentukan besar peluang untuk masing-masing nilai $\mathrm{z}$ berdasarkan tabel $\mathrm{z}$ dan diberi nama $\mathrm{F}(\mathrm{z})$.

d. Hitung frekuensi kumulatif relatif dari masing-masing nilai $\mathrm{z}$ dan sebut dengan $\mathrm{S}(\mathrm{z})$ hitung proporsinya, kalau $n=10$, maka tiaptiap frekuensi kumulaif dibagi dengan $\mathrm{n}$. Gunakan nilai Lhitung yang terbesar.

e. Tentukan nilai Lhitung $=|F(Z i)-S(Z i)|$ hitung selisihnya, kemudian bandingkan dengan nilai Ltabel dari tabel liliefors.

f. Jika Lhitung <Ltabel maka Ha diterima, sehingga dapat disimpulkan bahwa sampel berasal dari populasi yang berdistribusi normal.

\section{Teknik Pengolahan (Analisis) Data \\ Uji Koefisien Kolerasi}

Untuk mengetahui ada atau tidaknya pengaruh antara variabel bebas dengan variabel terikat. Dengan rumus korelasi Product moment yaitu:

$$
\mathrm{R}_{\mathrm{XY}}=\frac{N \sum X Y-\left(\sum X\right)\left(\sum Y\right)}{\left.\sqrt{\left(\left(N \sum X^{2}\right.\right.}-\left(\sum X\right)^{2}\right)\left(N \sum Y^{2}-\left(\sum Y\right)^{2}\right\}}
$$

(Arikunto $2018: 213$ )

\section{Keterangan:}

$R x y=$ Koefisioner korelasi Product moment

$N=$ Jumlah seluruh siswa

$\Sigma \mathrm{X}=$ Skor item

$\Sigma \mathrm{Y}=$ Skor total seluruh siswa 
$\Sigma \mathrm{XY}=$ Jumlah hasil perkalian antara skor " $\mathrm{X}$ " dan skor "Y"

\section{Uji t}

Untuk mengetahui apakah X memiliki Pengaruh yang signifikan (berarti) terhadap variabel Y dilakukan dengan pengujian terhadap hipotesis dengan menggunakan uji-t sebagai berikut:

$\mathrm{t}=r \frac{\sqrt{n-2}}{\sqrt{1-r^{2}}} \quad \ldots($ Sugiyono, $2018: 184)$

Keterangan:

$\mathrm{r}=$ Koefisioner Korelasi $\mathrm{n}=$ Sampel

Untuk mengetahui apakah hipotesis diterima $\left(\mathrm{H}_{\mathrm{a}}\right)$ maka $\mathrm{t}_{\text {hitung }}>\mathrm{t}_{\text {tabel }}$ begitu juga sebaliknya jika $t_{\text {hitung }}<t_{\text {tabel }}$ maka hipotesis ditolak $\left(\mathrm{H}_{0}\right)$.

\section{HASIL DAN PEMBAHASAN}

Hasil Pre Test yang telah dilaksanakan menunjukkan bahwa kemampuan hasil belajar siswa pada subtema komponen ekosistem Pre Test masih belum menggunakan model pembelajaran dan Post Test Menggunakan model pembelajaran PAKEM. Hal ini dapat dilihat pada tabel berikut ini:

Tabel 2. Hasil Nilai Rata-rata

\begin{tabular}{cccc}
\hline No & Jenis Perlakuan & Rata-rata & Kategori \\
\hline 1 & & & Kurang \\
2 & Pre Test & 47.40 & Baik Sekali \\
\hline
\end{tabular}

Untuk lebih jelas mengenai hasil nilai Rata-rata Pre Test dan Post test dapat dilhat pada diagram berikut ini:

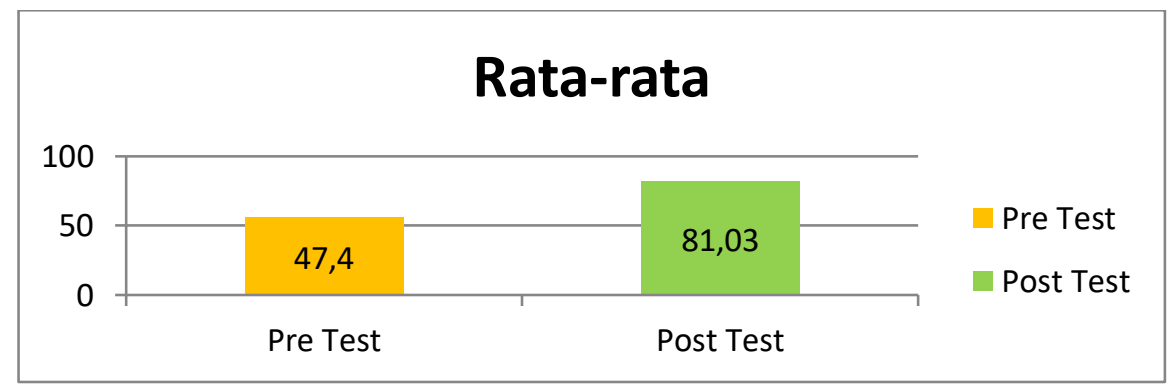

Gambar 1. Diagram Nilai Rata-Rata Pre Test dan Post Test

Berdasarkan data yang diperoleh dan nilai Pre Test dan Post Test dapat dilihat dari hasil ini dapat dilihat dari nilai Post Test hasil belajar lebih tinggi dari pada nilai Pre Test hasil belajar.
Dimana nilai rata-rata Post Test 81,03 sedangkan nilai Pre Test 47,4. Pada pembelajaran komponen ekosistem di SDN 067246 Medan Tuntungan. Kriterial penilaian untuk nilai Pre Test dan Post Test dapat dilihat pada tabel ini: 
Tabel 3. Kriteria Penilaian

\begin{tabular}{cc}
\hline Kriteria Penilaian & Keterangan \\
\hline $80-100$ & Baik Sekali \\
$70-79$ & Baik \\
$60-69$ & Cukup \\
$50-59$ & Kurang \\
$0-49$ & Gagal \\
\hline
\end{tabular}

\section{Uji Prasyarat}

Uji Normalitas

Uji Normalitas dilakukan untuk mengetahui apakah data dari Post Test hasil belajar kelas $\mathrm{V}$ terdistribusi normal atau tidak. Data yang diuji adalah data Pre
Test sebelum dilakukan tindakan atau tidak menggunakan perlakuan dengan data Post Test sesudah dilakukan tindakan dan perlakuan menggunakan model PAKEM. hasil perhitungan uji normalitas menggunakan program SPSS ver 22. Dapat dilihat pada tabel berikut ini:

Tabel 4. Uji Normalitas

\begin{tabular}{lllllll}
\hline & \multicolumn{3}{l}{ Kolmogorov-Smirnov ${ }^{\mathrm{a}}$} & \multicolumn{3}{l}{ Shapiro-Wilk } \\
\cline { 2 - 7 } $\mathrm{X}$ & Statistic & Df & Sig. & Statistic & Df & Sig. \\
\hline & .116 & 30 & $.200^{*}$ & .974 & 30 & .661 \\
\hline
\end{tabular}

\section{Uji Koefisien Korelasi}

Uji koefisien korelasi digunakan untuk mengetahui ada tidaknya pengaruh antara variabel bebas (X) variabel (Y), dan syarat untuk uji koefisien korelasi yaitu dengan melihat rhitung > rtabel.
Untuk melihat pengaruh dari kedua variabel dapat dilakukan dengan membandingkan antara rhitung dengan rtabel. Sedangkan uji koefisien korelasi berbantuan SPSS ver 22 pada tabel di bawah ini:

Tabel 5. Uji Koefisien Korelasi

\begin{tabular}{|c|c|c|c|}
\hline & & $\mathrm{X}$ & $\mathrm{Y}$ \\
\hline \multirow[t]{3}{*}{$\mathrm{X}$} & Pearson Correlation & 1 & $.652^{* *}$ \\
\hline & Sig. (2-tailed) & & .000 \\
\hline & $\mathrm{N}$ & 30 & 30 \\
\hline \multirow[t]{3}{*}{$\mathrm{Y}$} & Pearson Correlation & $.652^{* *}$ & 1 \\
\hline & Sig. (2-tailed) & .000 & \\
\hline & $\mathrm{N}$ & 30 & 30 \\
\hline
\end{tabular}

Dari tabel di atas menujukkan bahwa nilai koefisien korelasi sebesar 0,652.Dari tabel di atas nilai koefisien korelasi sebesar 0,652 artinya rhitung $(0,652)>$ rtabel $(0,361)$. Maka terdapat pengaruh yang kuat antara model pembelajaran PAKEM terhadap hasil belajar siswa dan terdapat pengaruh antara model pembelajaran
PAKEMterhadap hasil belajar siswa kelas V SDN 067246 Medan Tuntungan sebesar 67\% dan sebanyak 33\% dipengaruhi oleh faktor lain yang tidak dikaji dalam penelitian ini.

\section{Uji Hipotesis}


Setelah data dinyatakan berdistribusi normal dan sampel berasal dari populasi yang sama atau homogen, maka selanjutnya dapat dilakukan pengujian hipotesis menggunakan "uji t”. Statistik yang digunakan untuk menguji hipotesis penelitian adalah uji-t. Hipotesis yang diajukan adalah,

Ho : tidak ada pengaruh model pembelajaran PAKEM terhadap hasil belajar siswa
$\mathrm{Ha}$ : ada pengaruh model pembelajaran PAKEM terhadap hasil belajar siswa

Kriteria uji-t dapat dikatakan signifikan apabila diperoleh harga $\mathrm{p}<0,05$. Serta hipotesis diterima $(\mathrm{Ha})$ jika thitung $>$ ttabel dan di tolak (Ho) jika thitung $<$ ttabel . Hasil perhitungan hipotesis uji $t$ dapat dilihat pada tabel 4.9 di bawah ini:

Tabel 6. Uji-t

\begin{tabular}{|c|c|c|c|c|c|c|}
\hline & \multirow[b]{2}{*}{ Model } & \multicolumn{2}{|c|}{ Unstandardized Coefficients } & \multirow{2}{*}{$\begin{array}{c}\begin{array}{c}\text { Standardized } \\
\text { Coefficients }\end{array} \\
\text { Beta }\end{array}$} & \multirow[b]{2}{*}{$\mathbf{T}$} & \multirow[b]{2}{*}{ Sig. } \\
\hline & & $\overline{\mathrm{B}}$ & Std. Error & & & \\
\hline \multirow[t]{2}{*}{1} & (Constant) & -27.122 & 23.808 & & -1.139 & .264 \\
\hline & Religiusitas & 2.023 & .445 & .652 & 4.547 & .000 \\
\hline
\end{tabular}

\section{Pembahasan}

Penelitian ini dilakukan dikelas V SDN 067246 Medan Tuntungan.Untuk mengetahui kemampuan awal siswa, penelitian melakukan Pre Test dengan jumlah soal pilihan berganda, dan dengan jenis soal yang sama, diperoleh hasilnya dengan rata-rata 47.04 dapat dikatakan kemampuan awalnya kurang. Setelah melakukan Pre Test, peneliti menyampaikan materi dengan menggunakan model pembelajaran PAKEM. Di akhir pembelajaran, peneliti kembali memberikan Post Test untuk mengetahui tingkat keberhasilan. Hasil dari Post Test tersebut memiliki peningkatan dari hasil Pre Test yang diberikan sebelumnya. Hasil Post Test yang sudah diujikan sebesar 81.03 dapat dikatakan tingkat keberhasilan hasil belajarnya meningkat.

Hasil uji normalitas pada taraf signifikansi $(\alpha=0.05)$, dengan kriteria pengujian normalitas yaitu $\mathrm{L}_{\text {hitung }}<\mathrm{L}_{\text {tabel }}$ maka data berdistribusi normal dengan hasil $0.661<0.802$ maka data dapat dikatakan berdistribusi normal. Hasil koefisien korelasi membuktikan bahwa adanya pengaruh model pembelajaran PAKEM $(\mathrm{X})$ terhadap hasil belajar $(\mathrm{Y})$ dengan hasil $\mathrm{r}_{\text {hitung }}>\mathrm{r}_{\text {tabel }}$ dengan hasil $0.652>0.361$. Pada uji hipotesis dengan menggunakan uji-t dari perhitungan data yang dilakukan, hasil pengujian yaitu $t_{\text {hitung }}>t_{\text {tabel }}$ hasilnya $4.550>1.601$ dengan taraf signifikan $(\alpha=$
0.05). Dengan ini membuktikan bahwa adanya pengaruh yang signifikan dari penggunaan model pembelajaran PAKEM terhadap hasil belajar siswa pada tema Ekosistem kelas V SDN 067246 Medan Tuntungan. Berdasarkan hasil data yang diperoleh dari penelitian di SDN 067246 Medan Tuntungan dapat dikatakan bahwa dengan model pembelajaranPAKEM sangat efektif dalam pembelajaran tematik di kelas.

\section{SIMPULAN DAN REKOMENDASI}

Berdasarkan pembahasan bab ini peneliti menguraikan simpulan, implikasi, keterbatasan penelitian, dan saran yang disusun berdasarkan seluruh kegiatan penilitian mengenai pengaruh modelpembelajaran PAKEM (Pembelajaran Aktif, Kreatif, Efektif dan Menyenangkan) terhadap hasil belajar siswa kelas V 067246 Medan Tuntungan Tahun Pembelajaran 2020/2021 sebagai berikut : Pada kelas V dilakukan Pre Test dengan soal pilihan berganda, diperoleh hasil nilai terendah pre test 20 dan nilai tertinggi sebesar 76. Nilai rata-rata Pre Test 47,04 berada dengan kategori kurang. Kemudian di berikan perlakuan dengan menggunakan model pembelajaran PAKEM pada tema Ekosistem pembelajaran 1 di SDN 067246 Medan Tuntungan Tahun Pembelajaran 2020/2021 kelas V adalah nilai terendah 68 dan nilai tertinggi hasil post test 
sebesar 96. Nilai rata-rata Post Test 81.03 berada dengan kategori baik sekali. Model pembelajaran yang akan di isi siswa sesuai langkah-langkah pembelajaran yang telah dilaksanakan oleh guru dan siswa dengan nilai rata rata angket siswa yaitu sebesar 55.43. Nilai angket siswa terendah sebesar 49 dan nilai angket siswa tertinggi sebesar 58. Dengan persentase tertinggi sebesar $36.6 \%$ dan persentase terendah sebesar $13.3 \%$. Hasil uji uji korelasi sebesar 0.652 artinya $r_{\text {hitung }}>r_{\text {tabel }}$ yaitu $0.652>0.361$. Berdasarkan perhitungan hasil penelitian menunjukkan bahwa terdapat pengaruh model pembelajaran PAKEM terhadap hasil belajar siswa pada tema Ekosistem subtema Komponen Ekosistem di SDN 067246 Medan Tuntungan Tahun Pembelajaran 2020/2021 dengan thitung $>$ ttabel dimana $4.550>1.601$ pada taraf signifikan $\alpha=0.05$. Siswa dengan tema Ekosistem subtema Komponen Ekosistem. Dengan demikian $\mathrm{H}_{\mathrm{a}}$ diterima dan $\mathrm{H}_{\mathrm{o}}$ ditolak.

\section{DAFTAR PUSTAKA}

Amna, E. (2014). Penerapan Model Pembelajaran Kooperatif Tipe TPS di SMA Negeri 12 Banda Aceh. Jurnal Lantanida, 1(1), 6879.

Anzelina, D., Sinaga, R \& Silaban, P. J. (2021). Pengaruh Model Pembelajaran Pakem Terhadap Hasil Belajar Siswa Di Sekolah Dasar. Junal Basicedu, 5(1), 102-109.

Aslinda. (2017). Penerapan Model Pembelajaran Pakem Dalam Meningkatkan Hasil Belajar Pada Materi Sepak Bola Siswa Kelas Iv B Sd Negeri 013 Mekarsari. Primary Program Studi Pendidikan Guru Sekolah Dasar Fakultas Keguruan Dan Ilmu Pendidikan Universitas Riau, 6(2), 481.

Anzelina, D. (2019). Pengaruh Penggunaan Media Pembelajaran Video Terhadap Hasil Belajar Siswa Pada Tema Kayanya Negeriku Di Kelas Iv Sd Swasta St. Antonius V Medan. Prosiding Seminar Nasional Fakultas Ilmu Sosial Universitas Negeri Medan, 3(1), 752-761.

Anzelina, D., \& Sinaga, R. (2020). Peningkatkan Hasil Belajar Peserta Didik Menggunakan Media Audio Visual Tema Indahnya
Kebersamaan Kelas Iv. Education Fkip Unma, 6(2), 282-287.

Andriani, N., Asri, A. S., \& Ardana. (2019). Pembelajaran Ppkn Dengan Model Pakem Berbasis Tri Hita Karena Meningkatkan Kompetensi Pengetahuan Ppkn Siswa. Jurnal Pendidikan Dasar Ganesha, Bali, Indonesia, 1(2), 54-61.

Budimansyah, D., Suparlan, \& Meirawan, D. (2008). Pakem. Bandung: Pt Genesindo.

Fitriani. (2016). pengaruh motivasi belajar dan disiplin terhadap hasil belajar IPS siswa Di SMP Karya Indah Kecamatan Tapung. PeKA, 4(2), 137-142.

Gaol, R. L., \& Simarmata, E. J. (2019). efektifitas bahan ajar tematik sekolah dasar berbasis budaya lokal melalui penerapan model pembelajaran contextual teaching and learning (CTL) terhadap aktifitas belajar siswa. Jurnal Efektifitas Bahan Ajar Tematik Sekolah Dasar Berbasis Budaya, 3(4), 342-348.

Hamdani. (2018). Strategi Belajar Mengajar. Bandung: Pustaka Setia Bandung.

Istirani, \& Pulungan, I. (2019). Ensiklopedi Pendidikan. Medan: Media Persada.

Istiyanti. (2016). Model Pembelajaran Yang Aktif, Kreatif, Efektif, Dan Menyenangkan (Pakem). Jurnal Penelitian Dan Artikel Pendidikan, 3(1), 152-159.

Lestari, P., \& Hudaya, A. (2018). Penerapan Model Quantum Teachibg Sebagai Upaya Meningkatkan Hasil Belajar Siswa Pada Mata Pelajaran Ips Kelas Viii Smp Pgri 3 Jakarta. Of Education, 5(1), 45-60.

Melvin, T., \& Surdin. (2017). Hubungan Antara Disiplin Belajar Di Sekolah Dengan Hasil Belajar Geografi Pada Siswa Kelas X Sma Negeri 10 Kendari. Jurnal Penelitian Pendidikan Geografi, 1(1), 1-14.

Mahulae, S., \& Silaban, P. J. (2020). Pengaruh Model Pembelajaran Mind Mapping Terhadap Hasil Belajar Kelas 